\title{
GCU
}

Glasgow Caledonian

University

University for the Common Good

\section{Effect of silicon carbide particle size on microstructure and properties of a coating layer on steel produced by TIG technique \\ Munoz-Escalona, P.; Mridha, S.; Baker, T. N.}

Published in:

Advances in Materials and Processing Technologies

DOI:

$10.1080 / 2374068 \times .2016 .1246217$

Publication date:

2016

Document Version

Author accepted manuscript

Link to publication in ResearchOnline

Citation for published version (Harvard):

Munoz-Escalona, P, Mridha, S \& Baker, TN 2016, 'Effect of silicon carbide particle size on microstructure and properties of a coating layer on steel produced by TIG technique', Advances in Materials and Processing Technologies, vol. 2, no. 4, pp. 451-460. https://doi.org/10.1080/2374068X.2016.1246217

\section{General rights}

Copyright and moral rights for the publications made accessible in the public portal are retained by the authors and/or other copyright owners and it is a condition of accessing publications that users recognise and abide by the legal requirements associated with these rights.

Take down policy

If you believe that this document breaches copyright please view our takedown policy at https://edshare.gcu.ac.uk/id/eprint/5179 for details of how to contact us. 


\title{
Effect of Silicon Carbide Particle Size on Microstructure and Properties of a Coating Layer on Steel Produced by TIG Technique
}

\author{
P. Muñoz-Escalona ${ }^{a}$, S. Mridha ${ }^{b}$ and T.N. Baker ${ }^{c}$ \\ Department of Mechanical and Aerospace Engineering \\ University of Strathclyde, Glasgow, G1 1XJ, UK \\ ap.munoz@strath.ac.uk, bshahjahanmridha@gmail.com, cneville.baker@strath.ac.uk
}

Keywords: surface engineering, silicon carbide, particle size, TIG melting, Hardness

\begin{abstract}
Surface engineering is essential to prolong life of engineering components subject to deterioration in service from wear, erosion or corrosion, separately or in combination. This is possible by, for example, incorporating ceramic particles into a molten substrate surface, which may result in the partial or complete dissolution of the particles, and precipitation of a new phase, giving enhanced surface protection. Here, a single track surface zone of a micro-alloyed steel, was preplaced with a layer of $\mathrm{SiC}$ particles, with 1 or $75 \mu \mathrm{m}$ in size, melted at a constant heat input, with a tungsten inert gas (TIG) torch, using argon as shielding gas. The aim was to compare the melted track without $\mathrm{SiC}$ particles and when using $\mathrm{SiC}$ particles on the generated temperature, microstructure, melt dimension and hardness of the re-solidified surfaces.

Previous work has shown that microstructural changes occur along the track length due to preheating of the un-melted surface ahead of the molten zone. This effect was explored by inserting thermocouples along the $300 \mathrm{~mm}$ length of steel.

By optimizing the process parameters, a resolidified melt layer free of porosity has been achieved with $75 \mu \mathrm{m}$ size $\mathrm{SiC}$ particles. This melt reached a maximum hardness of $750 \mathrm{HV}$.
\end{abstract}

\section{Introduction}

The application of surface engineering techniques to improve the surface properties of carbon steels using high powered lasers for transformation hardening [1] and surface melting [2-4] is well established. More recently, a TIG torch technique has been explored for the surface modification of steels as a much cheaper option to lasers [5-8]. Previous studies have shown that the hardness of low alloy steels increased significantly when TiC in the form of powder, was incorporated through laser cladding [8] and the TIG melting technique [9-11].The development of improved wear resistance through the incorporation of $\mathrm{SiC}$ particles to produce metal matrix surface composites is well established in aluminum and titanium alloys by laser surface engineering [12-14]. With the exception of work by Terry and Chinyamakobvu [15], who studied the effect of an addition of SiC particles on the wear properties of steel, little attention has been paid to using SiC particles in iron and steels for this purpose. Majumdar et al [16], attempted to develop a compositionally gradient $\mathrm{SiC}$ dispersed phase to improve the wear properties of mild steel, through laser cladding. The SiC dissociated, and precipitated as $\mathrm{Fe}_{2} \mathrm{Si}$, raising the hardness from $190 \mathrm{HV}$ of the mild steel substrate to $\sim 600 \mathrm{HV}$ at the surface. The incorporation of $\sim 50 \mu \mathrm{m}$ size SiC particles into mild steel, by the use of TIG heating, undertaken by Reddy et al [17], increased the surface hardness to $\sim 400 \mathrm{HV}$. A linear increase in hardness with Si content, from the mild steel, $160 \mathrm{Hv}$ ( $\mathrm{Si} 0.23 \%$ ), to $400 \mathrm{HV}$ ( $\mathrm{Si}$ $1.5 \%$ ) was recorded. In a study by Patel et al [18], $5 \mu \mathrm{m} \mathrm{SiC}$ was dissolved into a microalloyed steel using a TIG torch, with argon as the shielding gas, to produce a modified surface of hardness $>1000 \mathrm{Hv}$ to a depth $\geq 1.4 \mathrm{~mm}$. Muñoz-Escalona et al [19], found that substituting helium for argon as the shielding gas in single track TIG processing, reduced hardness, due to the significantly higher temperatures recorded in the parent steel. Changes in heat input, shielding gas, and alloying powder composition, volume fraction and size, can also influence the surface roughness. In many 
applications, a low surface roughness parameter, $\mathrm{Ra}$, is demanded [20-22]. In other cases, the surface is required to have a machined finish [23, 24].

Therefore it is essential that the surface treatment produces a modified layer of such a thickness that it still provides the improved properties, such as wear or erosion resistance, over the life-time of the component. This research is a prerequisite to a wider study of TIG processing to create modified surfaces by powder alloying techniques having a superior wear and erosion properties.

\section{Experimental Method}

A surface engineering technique based on a Tungsten Inert Gas (TIG) torch was used to study the influence of two particle sizes 1 and $75 \mu \mathrm{m}$, on the microstructure and hardness of a microalloyed steel when using argon as shielding gas. The microalloyed steel substrate with composition of $0.1 \mathrm{C}$ $0.7 \mathrm{Mn}-0.05 \mathrm{Cu}-0.05 \mathrm{Nb}$ (all in wt. \%); had dimension $300 \times 30 \times 10 \mathrm{~mm}$, this chemical composition was determined using a Glow Discharge Optical Emission Spectrometer, model Horiba GD-OES profilometer.

In order to register the temperature along the melted track, thermocouples Type K were used. The substrate sample was divided into four sections by drilling three holes of $1 \mathrm{~mm}$ diameter and $5 \mathrm{~mm}$ depth from the underside of the $10 \mathrm{~mm}$ thick substrate to place three thermocouples. Each hole was located at distances of $75 \mathrm{~mm}$ each, dividing the melted track into four sections as observed in Fig. 1a.

$0.3 \mathrm{mg} \mathrm{SiC}$ particles were placed per squared millimeter area of substrate surface (along $300 \times 10$ mm space) and melted with a Miller Dynastry 300DX TIG equipment provided with a thoriated tungsten electrode to generate an arc with a $2.4 \mathrm{~mm}$ diameter. The electrode was direct current negative and the tip of the electrode was placed $1 \mathrm{~mm}$ above the specimen surface. Each sample was melted on the surface as shown in Fig. 1b. Three samples were developed, one sample with no particle addition, and two other samples using the two particle sizes investigated ( 1 and $\sim 75 \mu \mathrm{m}$, both average). Experiments were conducted at a constant heat input of $\sim 835 \mathrm{~J} / \mathrm{mm}$. For the sample melted without $\mathrm{SiC}$ particles the following combination of cutting parameters were used $80 \mathrm{~A}, 11 \mathrm{~V}$ and $0.5 \mathrm{~mm} / \mathrm{s}$; and a combination of $145 \mathrm{~A}, 12 \mathrm{~V}$ and $1 \mathrm{~mm} / \mathrm{s}$ for the samples melted with $\mathrm{SiC}$ particles. These combinations were used in order to reach the $\sim 835 \mathrm{~J} / \mathrm{mm}$ requiered. The shielding gas flow rate was kept at $10 \mathrm{~L} / \mathrm{min}$ during the whole melting process. Table 1 shows thermal related properties of the materials involved

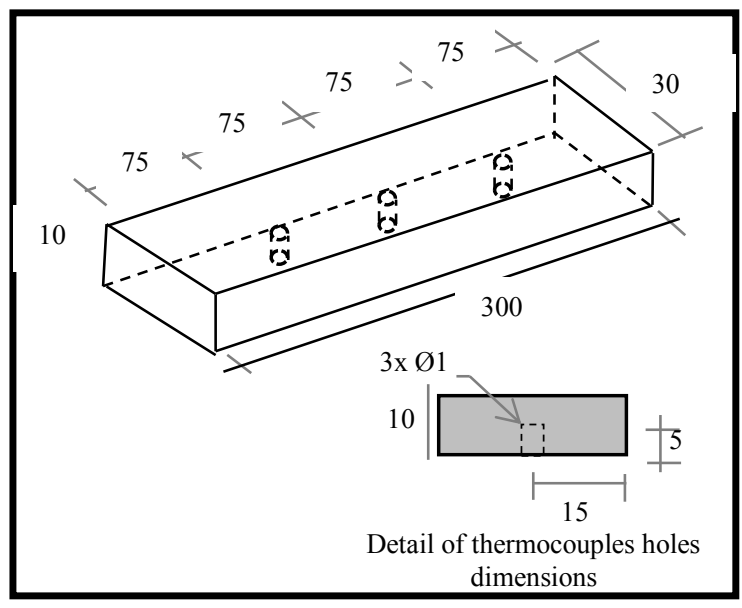

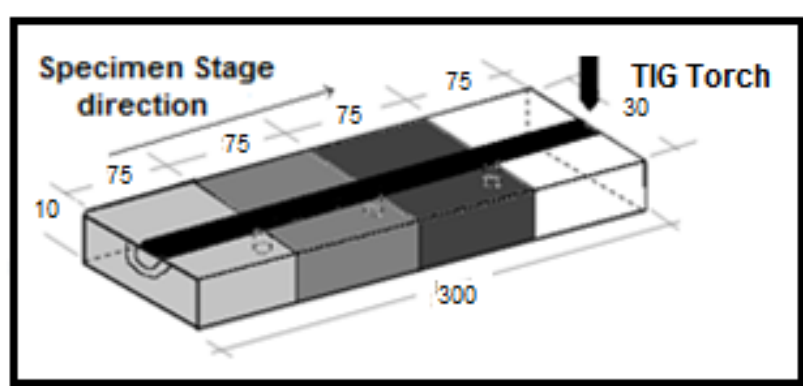

b)

a)

Fig 1. Schematic TIG melted surface. a) Sample's dimensions and location of thermocouple b) location of melted track and melting direction 
The energy input was calculated using Eq. 1.

$$
\mathrm{E}=\eta \mathrm{VI} / \mathrm{s}
$$

where $\eta$ is the efficiency of energy absorption, which was taken as $48 \%$ for a TIG process [20]

Table 1. Properties of steel, SiC particles and shielding gas used in the experiment

\begin{tabular}{|l|c|c|c|}
\hline \hline \multirow{2}{*}{ Property } & Material & Mild steel & Argon \\
\cline { 1 - 3 } Density $\left[\mathrm{kg} / \mathrm{m}^{3}\right]$ & & 3210 & 1.67 \\
\hline Specific heat $\left[c_{\rho} / \mathrm{kJ} \mathrm{Kg} \mathrm{K}\right]$ & 0.45 & 0.75 & 0.52 \\
\hline Thermal conductivity $[\mathrm{W} / \mathrm{m} \mathrm{K}]$ & 49.8 & $80(\mathrm{HP}) 71($ sintered $) 490(\alpha \mathrm{Sic})$ & 0.016 \\
\hline Specific gravity & 7.8 & 3.2 & 1.38 \\
\hline
\end{tabular}

Once the melting process was completed, the samples were allowed to cool at room temperature prior to microstructural determination and microhardness analysis. Each sample was analyzed just beyond the location of each thermocouple, giving a total of three specimens from each sample. Specimens were prepared for metallographic analysis using the conditions described in ASTM E301 standards

The microhardness measurements were conducted following BS 1043-2 1993 and BS6507-1 1998. The cross-sectional area of each sample, the fusion zone (FZ), the heat affected zone (HAZ) and the parent material (PM), was measured starting at $0.1 \mathrm{~mm}$ from the fusion zone edge and taking measurements in a vertical distance at $0.2 \mathrm{~mm}$ apart, towards the parent material as observed in Fig. 2. These readings were taken using a Mitutoyo MVK G1 microhardness tester with $200 \mathrm{gf}$ load and a 15 s delay.

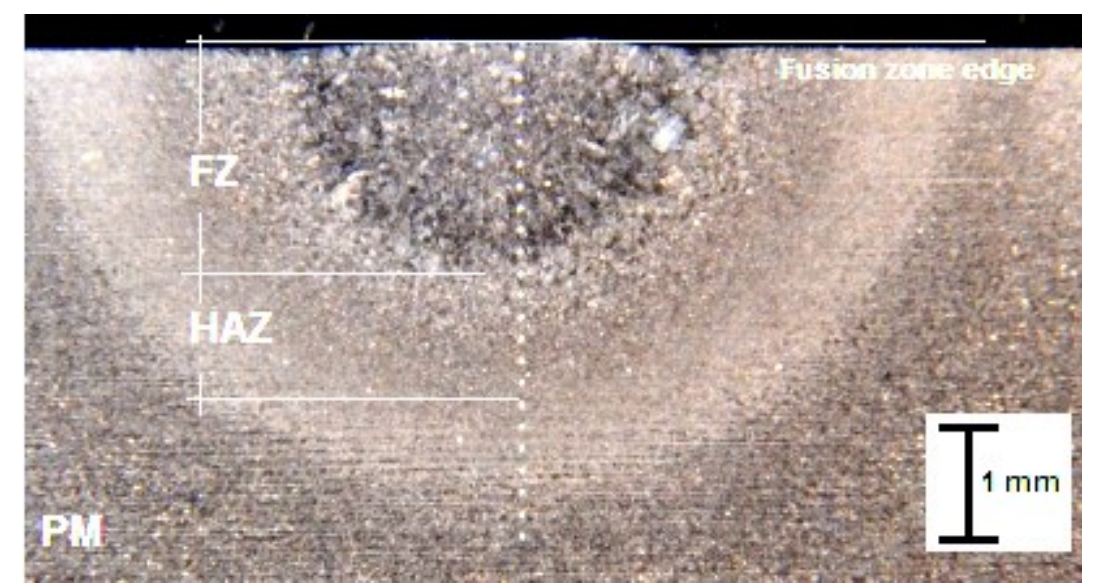

Fig. 2. Pattern of indents taken on melt cross section of the track. 
Fig. 3 shows the temperatures registered by the thermocouples when using a heat input $\sim 835 \mathrm{~J} / \mathrm{mm}$ to melt samples with free of $\mathrm{SiC}$ particles and with $\mathrm{SiC}$ particles of 1 and $75 \mu \mathrm{m}$.

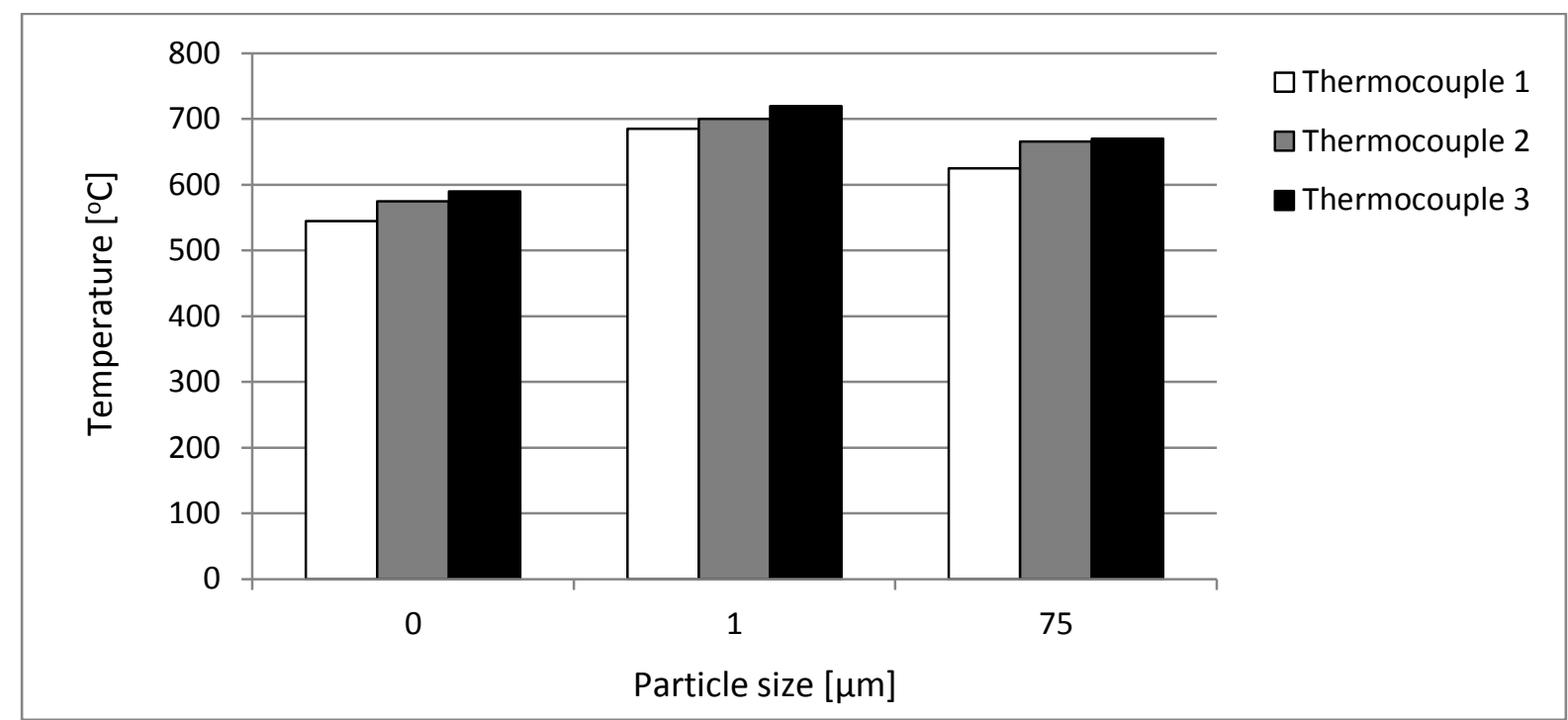

Fig. 3. Temperature versus SiC particle size registered by each thermocouple when using a heat input rate of $835 \mathrm{~J} / \mathrm{mm}$

As expected when analyzing Fig. 3, in general there are higher values of temperature registered at the end of the melted track, where an average increase of $\sim 50 \mathrm{C}$ was obtained between the start and the end of the melted track. This small increase is associated to a pre-heat process [18-19]. As observed, the temperature increased when $\mathrm{SiC}$ particles were incorporated.

Fig. 4 shows the cross-sectional areas of the melted region for specimens obtained at the $75 \mathrm{~mm}$, $150 \mathrm{~mm}$ and $225 \mathrm{~mm}$ positions, from the start of melting, along the direction of the melt track. As observed, in general all sections presented a consistent regular cross-sectional area along the whole track and samples associated with higher particle size presented a bigger cross sectional area. However, central cracks where observed in the fusion zone at the end of the melted track. From the literature these cracks are called hot cracks and are due to the solidification process [25]. The formation of these cracks were probably due to the presence sulphur inside of the crack, as observed when conducting EDX analysis, as no sulphur was found in either side of the crack. 


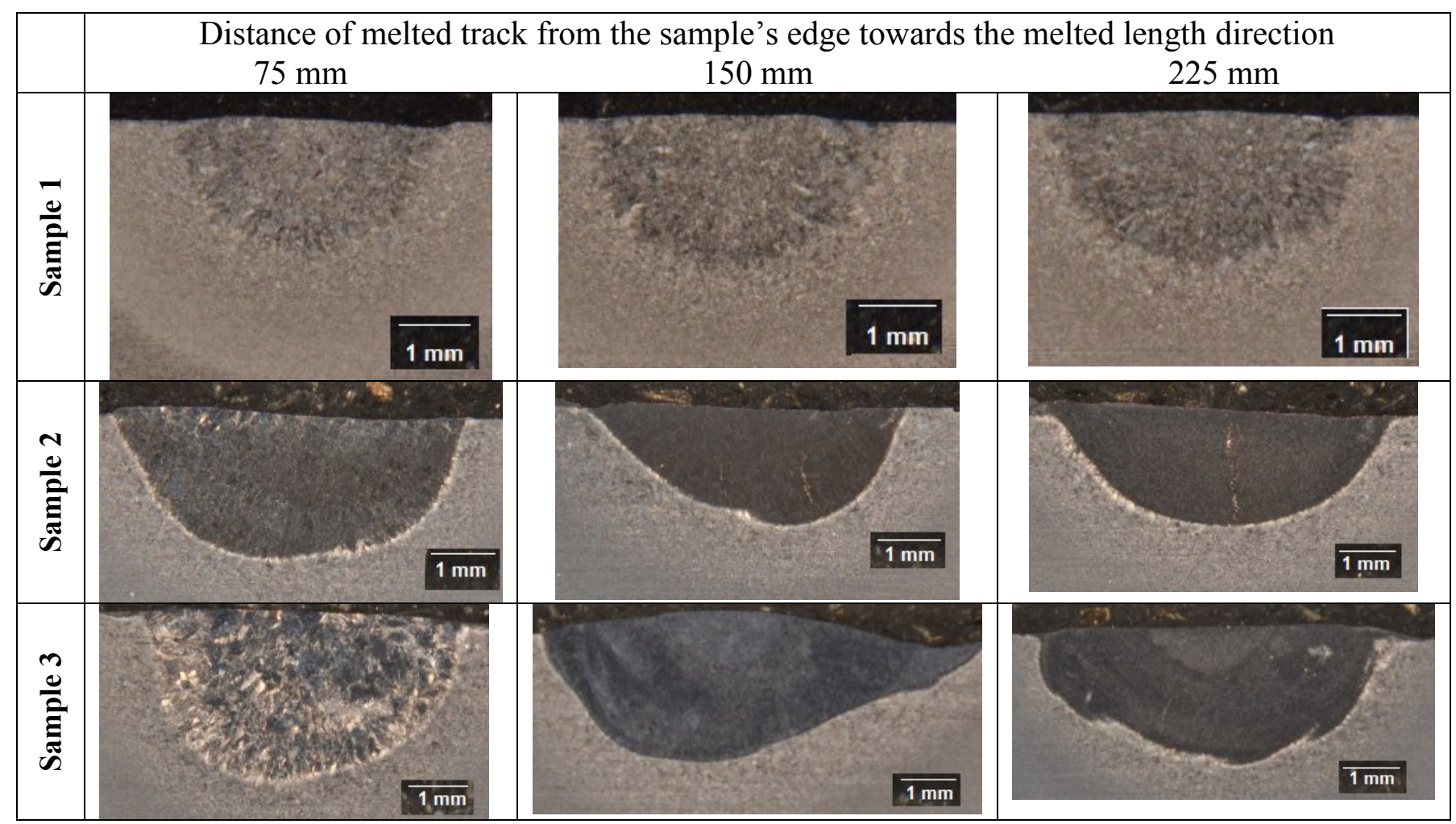

Fig. 4. Melt pool cross sections at different distances from sample's edge towards the end of the melted track. Sample 1: free of $\mathrm{SiC}$ particles, Sample 2: melted with $\mathrm{SiC}$ with $1 \mu \mathrm{m}$ particle size, Sample 3: : melted with $\mathrm{SiC}$ with $75 \mu \mathrm{m}$ particle size

The dimensions of the fusion zones at different distances from the sample's edge are given in Fig. 5 , whereas as noted above, a wider cross-sectional area and a slight increase in depth is obtained when using larger particles size.

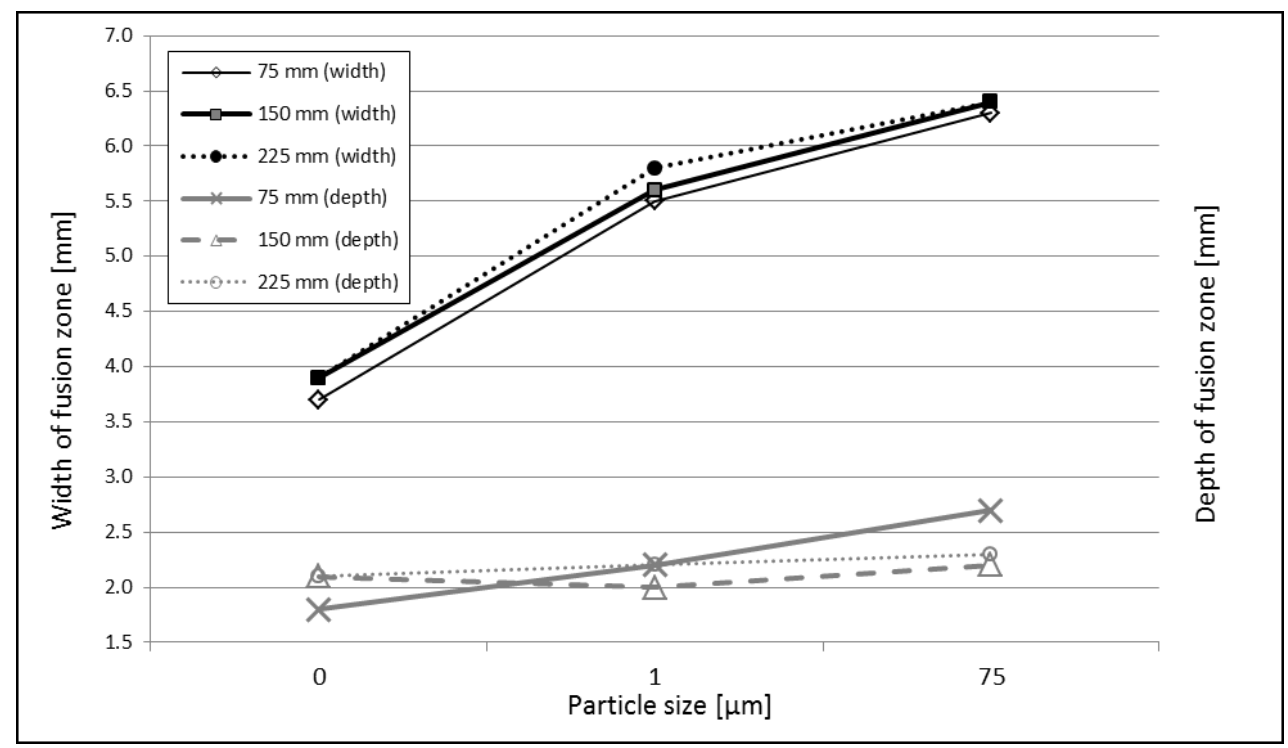

Figure 5 Dimensions of the fusion zone at different distances from the sample's edge towards the end of the melted track when increasing $\mathrm{SiC}$ size $(0=$ no $\mathrm{SiC}$ addition) 
Fig. 6 shows the hardness profile of the cross-sectional area of the three samples under study.

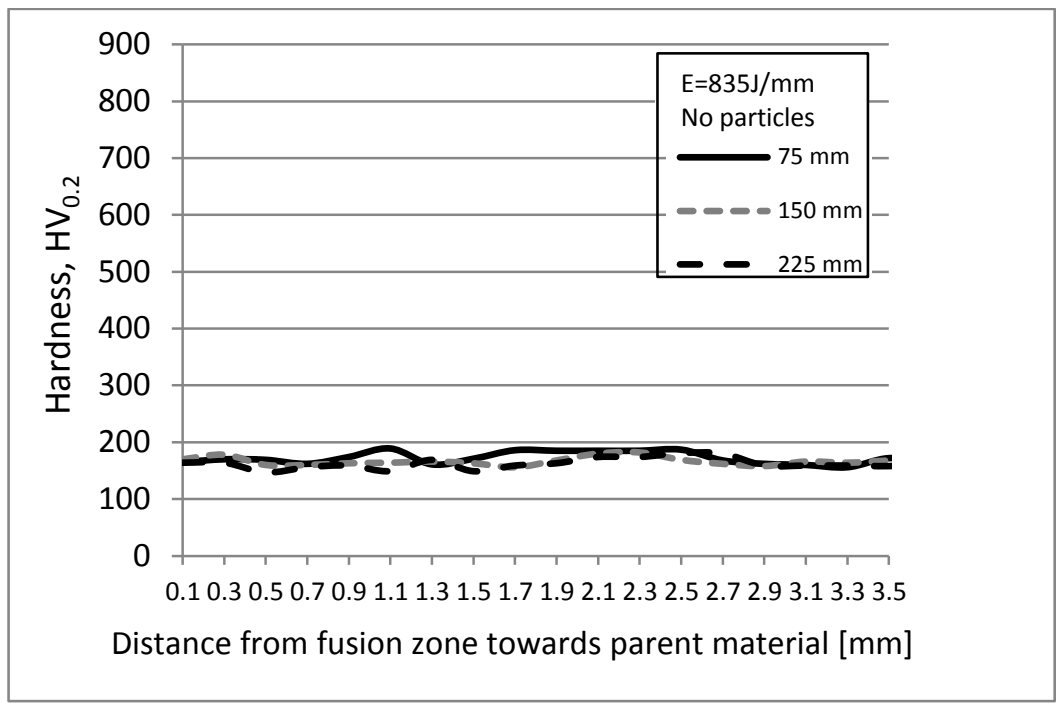

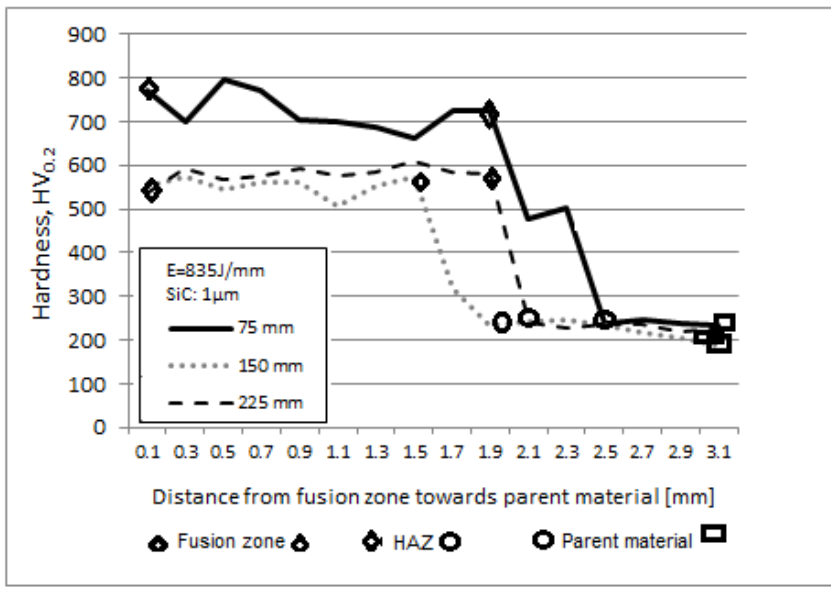

b)

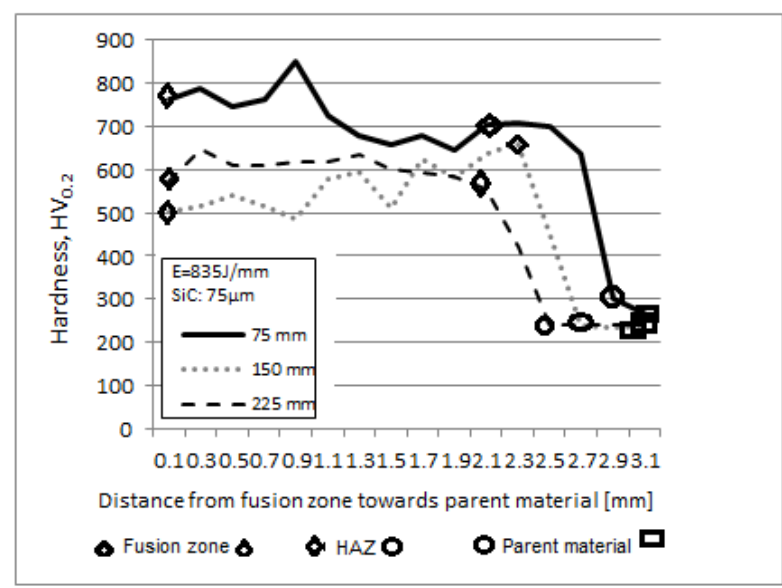

c)

Fig. 6. Cross-sectional area hardness profile of samples melted at $835 \mathrm{~J} / \mathrm{mm}$

a) Sample 1: free of particles, b) Sample 2: $\mathrm{SiC}$ with particle size of $1 \mu \mathrm{m}$ and c) Sample 3: $\mathrm{SiC}$ with particle size of $75 \mu \mathrm{m}$

As observed in Fig. 6, there is a huge difference in hardness when comparing the sample melted without SiC particles (Fig 6a), with samples covered with $\mathrm{SiC}$ particles, where the maximum hardness in the fusion zone reached $850 \mathrm{HV}$, followed by the highest hardness values in the HAZ and finally the parent material. It can also be seen that the lowest values of hardness were obtained at the end of the melted track, where higher values of temperatures were recorded; and as a consequence a slower cooling rate due to the preheating condition this part of the sample was subjected.

Lower values of hardness at the start of the melted track for Sample 1 (free of SiC particles) were also observed. This result was expected as these areas were subjected to heat and the material went through an annealing process.

Fig. 7 shows the microstructure of the fusion zone with the maximum value of hardness reported, at the start and at the end of the melted track $(75 \mathrm{~mm}$ and $225 \mathrm{~mm})$ when using different melting conditions 


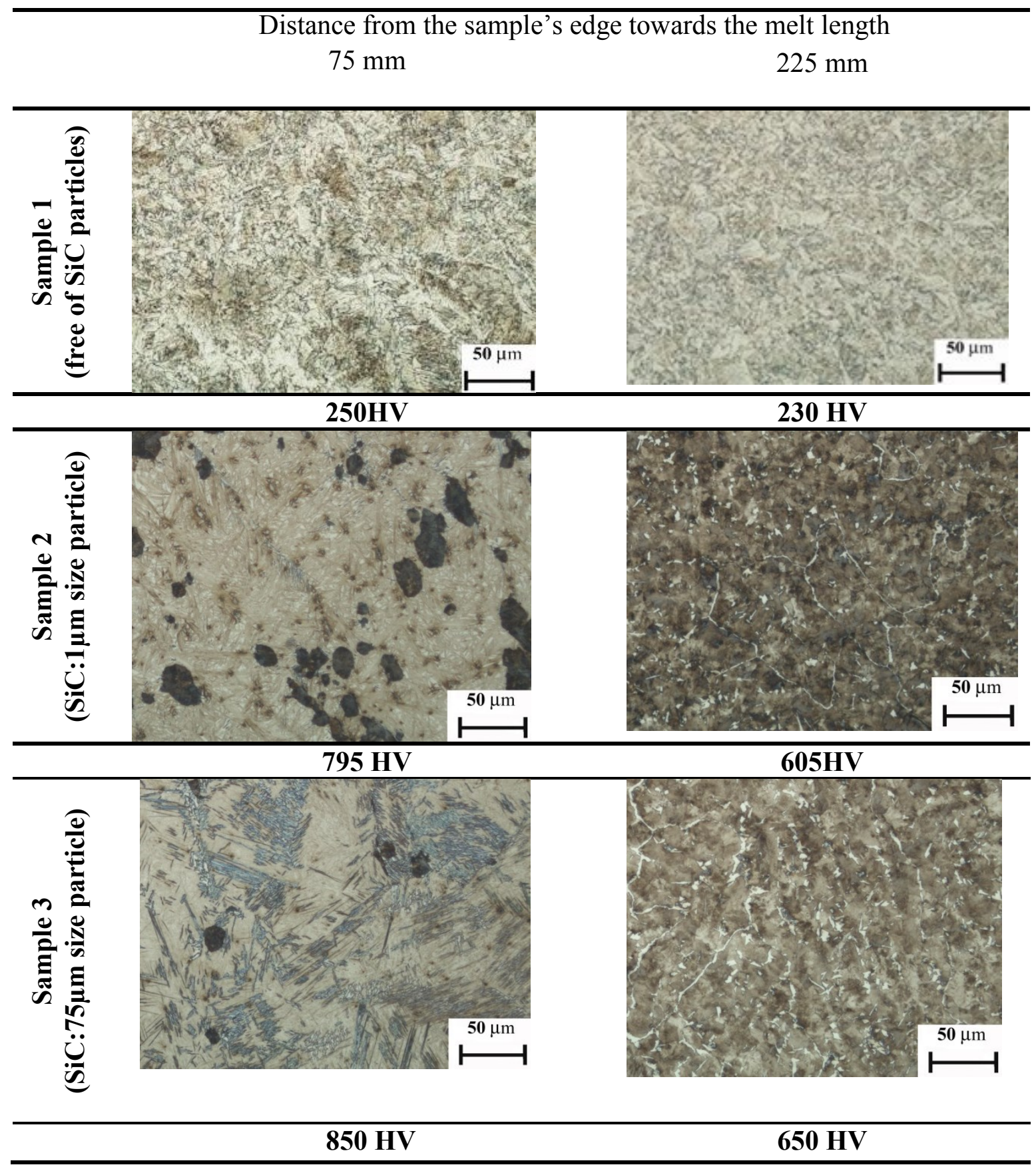

Fig. 7. Microstructures of the Fusion Zone at the start and the end of the melted track.

When analysing and relating the results from the microstructure (Fig.7) and hardness (Fig 6) it is observed that the preheating produced significant changes in the microstructure, especially in sample 2 and sample 3 which included the SiC particles $(1 \mu \mathrm{m}$ and $75 \mu \mathrm{m}$ particle size respectively). This was reflected by the values of hardness obtained at the start and end of the melted track. As previously mentioned, an increase of only $50{ }^{\circ} \mathrm{C}$ in the maximum temperature was obtained between the start and end of the melted track, which appears to be sufficient to produce the changes recorded in this work.

Also apparently different changes were obtained when comparing the particle size used in each sample. Also a more homogeneous microstructure was obtained in sample 1 (free of SiC particles. 
Figs. 8 and 9 show examples of SEM micrographs obtained from the different samples.

Fig. 8 shows a SEM image of sample 2, from two different areas of the fusion zone (near the surface and bottom), which was melted at $\mathrm{E}=835 \mathrm{~J} / \mathrm{mm}$ with $1 \mu \mathrm{m} \mathrm{SiC}$.

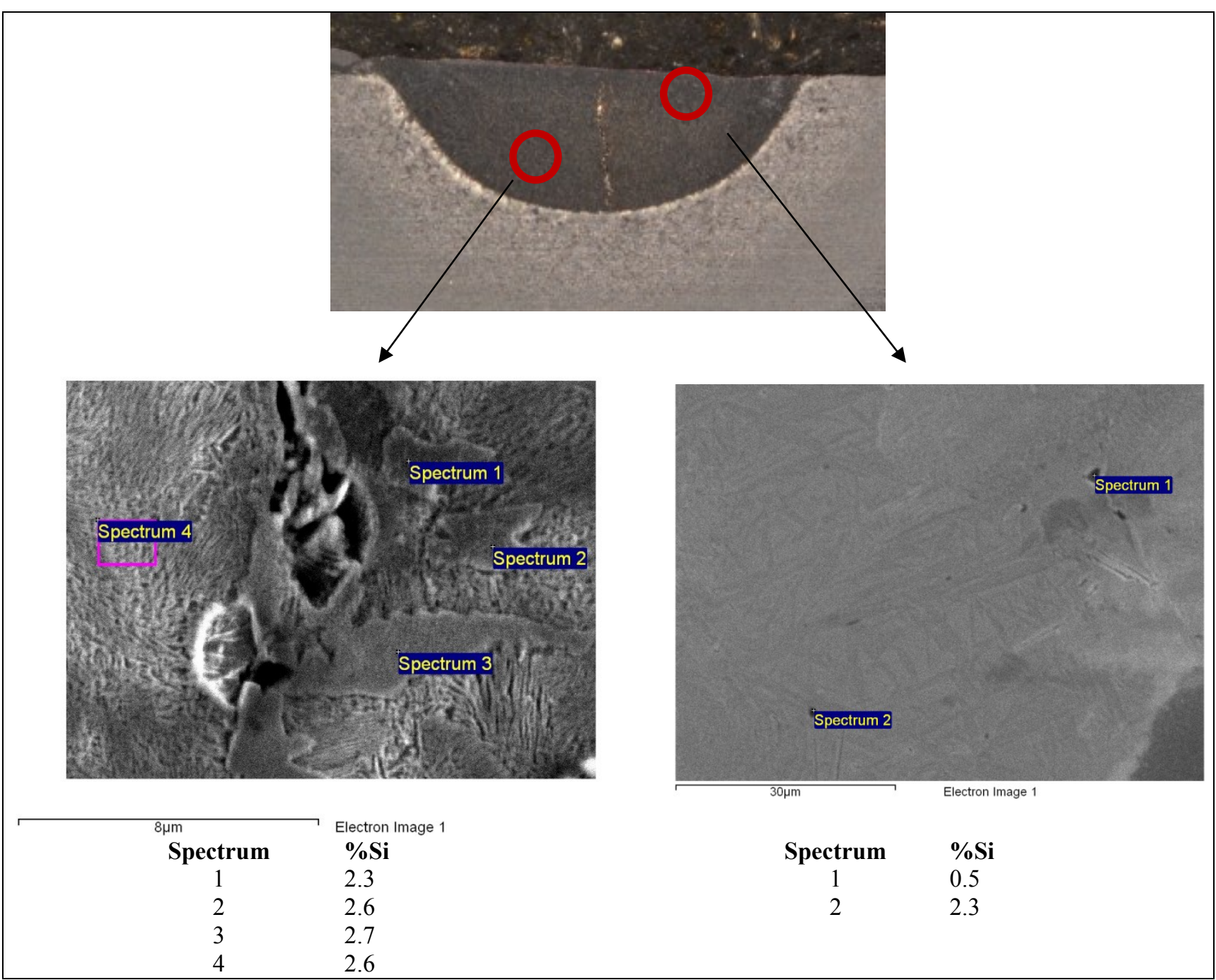

Fig. 8. SEM image in different locations for sample $2(E=835 \mathrm{~J} / \mathrm{mm} \quad \mathrm{SiC}-1 \mu \mathrm{m})$

As observed when analyzing Fig. 8, the silicon content obtained by EDX, increases from $0.5 \% \mathrm{Si}$, near the top of fusion zone, spectrum 1 right hand picture, to $2.5 \%$ average $\mathrm{Si}$, in the bottom of the fusion zone (left hand picture). This silicon comes from dissociation of the SiC powder that was deposited on top of the steel substrate, and incorporated into the melt zone.

A similar behavior is observed in Fig. 9, where SEM images and EDX from sample 3 with $75 \mu \mathrm{m}$ $\mathrm{SiC}$ and melted at $835 \mathrm{~J} / \mathrm{mm}$ are shown. In Fig 9a, two indentations near the fusion zone-heat affected zone interface can be seen. The hardness values obtained from these indentations are 638 $\mathrm{HV}_{0.2}$ for the fusion zone and $302 \mathrm{HV}_{0.2}$ for heat affected zone. These results show the drastic decrease in hardness from the fusion zone to the heat affected zone, which is supported by the hardness profile shown in Fig $6 \mathrm{~b}$ and Fig. $6 \mathrm{c}$. 


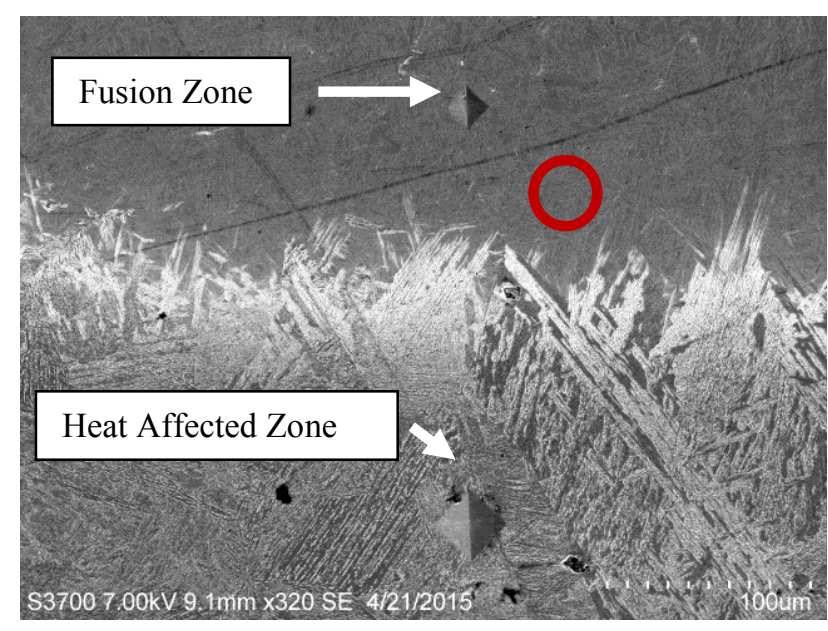

a)

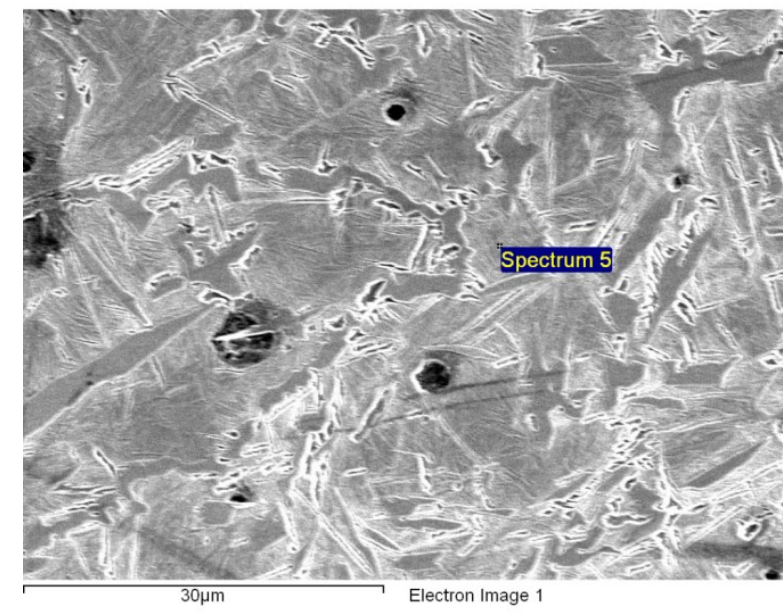

Spectrum 5: $2.8 \% \mathrm{Si}$

b)

Fig. 9. SEM image and EDX analysis of sample $3(E=835 \mathrm{~J} / \mathrm{mm}$ and SiC: $75 \mu \mathrm{m})$ a) Interface between fusion zone and heat affected zone showing hardness indentation b) SEM image with the location of the spectrum shown in a)

Also, as observed from Fig 9b, the EDX analysis corresponding to the bottom of the melted zone shows the presence of $2.8 \% \mathrm{Si}$.

\section{Conclusions}

In a study, in which the surface melting of a single track on a micro-alloyed steel using a tungsten inert gas (TIG) torch, with argon as shielding gas, compared an uncoated surface with those after incorporating a preplaced layer of $\mathrm{SiC}$ particles, of average size 1 or $75 \mu \mathrm{m}$, it was found that:

The presence of pre-heating as a consequence of the melting technique used in the experiments, produced changes in microstructures and hardness along the melted track, especially after preplacing $\mathrm{SiC}$ particles of the microalloyed steel surface. These changes were observed at the end of the melted track and when a difference of $\sim 50{ }^{\circ} \mathrm{C}$ between the start and the end of the melted track occurred,

A uniform cross sectional area of the track was obtained, and an increase of the particle size produced an increase of the width of the fusion zone, but had little influence on the depth.

Incorporation of $\mathrm{SiC}$ into the microalloy steel surface produced an increase of almost $300 \%$ of the surface hardness (from $200 \mathrm{HV}$ to $800 \mathrm{HV}$ )

$\mathrm{SiC}$ particles of both sizes were taken into solution in the molten steel surface, with little trace of undissolved particles observed in the resolidified track. A higher percentage of silicon was recorded at the bottom of the fusion zone than in the surface, independently of the particle size 


\section{Acknowledgments}

The authors would like to thank Gerard Johnston, James Kelly and Steven Black, for their technical support.

\section{References}

[1] Bach R, Damascheck E, Geissler, et al. In: Bergmann HW, Kupfer R, editors. Proc. 3rd European Conf. on Laser Treatment of Materials (ECLAT'90). Coberg, Sprwechsaal. Publishing Group.1990. p. 265-282..

[2] Ayers JD, Schaefer RJ. In: Ready JF, editor. Proc. Conf. 'Laser applications in material processes'.Bellingham: SPIE; 1979. p. 57-64.

[3] Dahotre N.B and Mukherje K. Development of microstructure in laser surface alloying of steel with chromium. Mater. Sci. Vol. 25, (1990), p. 445-454.

[4] Fasasi AY, Pons M, Tassin C, et al. Laser surface melting of mild steel with submicronic titanium carbide powders J. Mater. Sci. Vol. 29, (1994), p. 5121-5126.

[5] S. Atamert and H.K.D.H.Bhadeshia:Metall.Trans.A, Vol.20A, (1989),1037-1054.

[6] T.I. Khan and D.Fowles:Surf.Eng., Vol.13,(1997),257-259.

[7] S. Mridha and B.S.Ng, Surf.Eng., Vol.15,(1999),210-215.

[8] J.H. Ouyang, Y.T. Pei, T.C. Lei and Y. Zhou: Wear,Vol.185, (1995),p. 167-172.

[9] S. Mridha, A.N. Md Idriss, M.A. Maleque, Suryanto and A. Souad:Int. J. Mech. Mat. Eng.,Vol.1,(2012),p. 48-53.

[10] S. Mridha, A.N. Md Idriss and T.N. Baker: Adv. Mat. Res.,Vol.445,(2012),p. 655- 660.

[11] S. Mridha, A.N. Md Idriss, M.A. Maleque, I.I. Yaacob and T.N.Baker: Mater.Sci.Technol.,Vol.31,(2015),p1362-1369.

[12] T. N. Baker, H. Xin, C.Hu and S.Mridha:Mater.Sci.Technol.Vol.10, (1994), p.536-544.

[13] S. Mridha and T. N. Baker: Mater. Sci. Technol. Vol. 12, (1996), p.595-602.

[14] S. Mridha and T. N. Baker: J. Mater. Proc. Technol., Vol.63,(1997), p.432-437.

[15] B. S. Terry and O. S. Chinyamkobvu: J. Mater. Sci., Vol.28,(1993), p.6779-6784.

[16] J. Dutta Majumdar, B. R. Chandraa, A.K. Nathb, and I. Mannaa J.Mater.Proc.Technol.,Vol.203, (2008),p. 505-512.

[17] G. H. Reddy, S. Arul and R.Sellamuthu:Appl.Mech.Mater.Vols.592-594, (2014), p.879-882.

[18] Patel P, Mridha S, Baker TN. "Influence of Shielding Gases on Preheat Produced in Surface Coatings Incorporating SiC Particulates into Microalloy Steel using TIG Technique", Materials Science and Technology, Vol. 30, (2014), p. 1506-1514. 
[19] P. Muñoz de Escalona, S. Mridha and T. N. Baker: Effect of shielding gas on the properties and microstructure of melted steel surface using a TIG torch. Advances in Materials and Processing Technologiess.Vol XX, No XX, 1-9

[20] Information on http://www.hallite.com/upload/surface.pdf

[21] Information on http://net.grundfos.com/doc/webnet/mining/downloads/pump-handbook.pdf

[22] Information on http://www.in-situ.co.uk/crankshaft-machining

[23] Choi Y, Liu C, Richard. Int. Performance of nano/micro CBN particle coated tools in superfinish hard machining. J.Mach. Tools Manu. Vol. 49, (2009), p. 683-689

[24] Uhlman E, Fuentes JA, Keunecke M. Machining of high performance workpiece materials with CBN coated cutting tools: Thin Solid Films, Vol. 518, (2009), p. 1451-1454

[25] Information on http://www.welding-consultant.com/WeldCracks.pdf 